Article (refereed) - postprint

Gurnell, A.M.; Rinaldi, M.; Belletti, B.; Bizzi, S.; Blamauer, B.; Braca, G.;

Buijse, A.D.; Bussettini, M.; Camenen, B.; Comiti, F.; Demarchi, L.; Garcia de Jalon, D.; Gonzalez del Tanago, M.; Grabowski, R.C.; Gunn, I.D.M.;

Habersack, H.; Hendriks, D.; Henshaw, A.J.; Klosch, M.; Lastoria, B.; Latapie, A.; Marcinkowski, P.; Martinez-Fernadez, V.; Mosselman, E.; Mountford, J.O.; Nardi, L.; Okruszko, T.; O'Hare, M.T.; Palma, M.; Percopo, C.; Surian, N.; van de Bund, W.; Weissteiner, C.; Ziliani, L. 2016. A multi-scale hierarchical framework for developing understanding of river behaviour to support river management. Aquatic Sciences, 78 (1). 1-16. 10.1007/s00027-015$\underline{0424-5}$

C Springer Basel 2015

This version available http://nora.nerc.ac.uk/509977/

NERC has developed NORA to enable users to access research outputs wholly or partially funded by NERC. Copyright and other rights for material on this site are retained by the rights owners. Users should read the terms and conditions of use of this material at http://nora.nerc.ac.uk/policies.html\#access

This document is the author's final manuscript version of the journal article, incorporating any revisions agreed during the peer review process. There may be differences between this and the publisher's version. You are advised to consult the publisher's version if you wish to cite from this article.

The final publication is available at Springer via http://dx.doi.org/10.1007/s00027-015-0424-5 
The following paper is the final version prior to publication on 22 September 2015.

The final publication is available at Springer via http://dx.doi.org/10.1007/s00027-015-0424-5

\section{A MULTI-SCALE HIERARCHICAL FRAMEWORK FOR DEVELOPING UNDERSTANDING OF RIVER BEHAVIOUR TO SUPPORT RIVER MANAGEMENT.}

A.M. Gurnell ${ }^{1 \star}$, M. Rinaldi², B. Belletti ${ }^{2}$, S. Bizzi ${ }^{3}$, B. Blamauer ${ }^{4}$, G. Braca ${ }^{5}$, A.D. Buijse 6 , M. Bussettini ${ }^{5}$,

B. Camenen 7 , F. Comiti, L. Demarchi³, D. García de Jalón ${ }^{9}$, M. González del Tánago ${ }^{9}$, R.C. Grabowski $^{10}$, I.D.M. Gunn ${ }^{11}$, H. Habersack ${ }^{4}$, D. Hendriks ${ }^{6}$, A.J. Henshaw ${ }^{1}$, M. Klösch ${ }^{4}$, B. Lastoria ${ }^{5}$, A. Latapie $^{7}$, P. Marcinkowski ${ }^{13}$, V. Martínez-Fernández ${ }^{9}$, E. Mosselman ${ }^{6,14}$, J.O. Mountford ${ }^{12}$, L. Nardi², T. Okruszko ${ }^{13}$, M.T. O'Hare ${ }^{11}$, M. Palma ${ }^{15}$, C. Percopo ${ }^{5}$, N. Surian ${ }^{15}$, W. van de Bund ${ }^{3}$, C. Weissteiner ${ }^{3}$ and L. Ziliani ${ }^{15}$

* Corresponding author, email: a.m.gurnell@qmul.ac.uk

1 School of Geography, Queen Mary University of London, UK.

2 Department of Earth Sciences, University of Florence, Italy

3 Institute for Environment and Sustainability (IES), Water Resources Unit, European Commission, Joint Research Centre (JRC), Ispra, (VA), I-21027 Italy

4 Christian Doppler Laboratory of Advanced Methods in River Monitoring, Modelling and Engineering, Institute of Water Managment, Hydrology and Hydraulic Engineering, University of Natural Resources and Life Sciences Vienna, Vienna, Austria

5 Istituto Superiore per la Protezione e la Ricerca Ambientale (ISPRA), Water Protection Department, Rome, Italy.

6 Deltares, Boussinesqweg 1, 2629 HV Delft, the Netherlands

7 Irstea Lyon, UR HHLY, Villeurbanne, France

8 Faculty of Science an Technology, Free University of Bozen-Bolzano, Italy

9 ETSI Montes, Universidad Politecnica de Madrid, Spain

10 Cranfield Water Science Institute, Cranfield University, UK

11 NERC - Centre for Ecology \& Hydrology, Bush Estate, Penicuik, Midlothian, UK

12 NERC - Centre for Ecology \& Hydrology, Maclean Building, Benson Lane, Crowmarsh Gifford, Wallingford, Oxfordshire, UK

13 Department of Water Engineering, Faculty of Civil and Environmental Engineering, Warsaw University of Life Sciences, Warszawa, Poland.

14 Faculty of Civil Engineering and Geosciences, Delft University of Technology, Stevinweg 1, 2628 CN Delft, The Netherlands

15 Department of Geosciences, University of Padova, Padova, Italy 


\section{ABSTRACT}

This paper introduces this special issue of Aquatic Sciences. It outlines a multi-scale, hierarchical framework for developing process-based understanding of catchment to reach hydromorphology that can aid design and delivery of sustainable river management solutions. The framework was developed within the REFORM (REstoring rivers FOR effective catchment Management) project, funded by the European Union's FP7 Programme. Specific aspects of this 'REFORM framework' and some applications are presented in other papers in this special issue.

The REFORM framework is founded on previous hierarchical frameworks, sixteen examples of which are reviewed. However, the REFORM framework has some particular properties that reflect the European context for which it was developed.

The framework delineates regional landscapes into nested spatial units at catchment, landscape unit, segment, reach, geomorphic unit and finer scales. Reaches, regardless of their 'naturalness', are assigned to a river type based on valley confinement, planform and bed material.

Indicators are quantified at each spatial scale to feed three groups of assessments. First, contemporary indicators at reach and geomorphic unit scales investigate present processes, forms and human pressures within each reach. These feed assessments of present reach hydromorphological function / alteration, including whether the reach is functioning appropriately for its type; riparian corridor function and alteration; and hydromorphological adjustment. Second, indicators at catchment to segment scales investigate water and sediment production and delivery to reaches and how these are affected by human pressures now and in the past. These are used to construct an inventory of changes over space and time. Third, historical reach and geomorphic unit scale indicators are used to construct the trajectory of reach-scale changes. Contemporary reachscale assessments, space-time inventory, and trajectory of changes are then combined to establish how river reaches of different type, subject to different human pressures, and located in different environmental contexts behave in response to changes at all considered spatial scales. These support forecasts of the likely responses of reaches to future scenarios (e.g. changes in climate, land cover, channel interventions).

\section{KEYWORDS}

REFORM framework, Space scale, Time scale, Hydromorphology, River management, River rehabilitation. 


\section{AN INTRODUCTION TO HIERACHICAL FRAMEWORKS FOR ASSESSING THE HYDROMORPHOLOGY OF RIVER SYSTEMS}

This paper introduces this special issue of Aquatic Sciences by outlining the multi-scale, hierarchical framework that has been developed for improving hydromorphological understanding and informing management of rivers, particularly in a European context. Here the term hydromorphology, which is used widely within Europe, refers to the suite of hydrological and geomorphological processes and forms that occur within catchments and their river systems. This paper provides the rationale behind the development of the framework and briefly overviews its structure and key features including the way that it supports understanding of the hydromorphological behaviour of river reaches in response to temporal changes at catchment to reach scales. It also refers to other papers within this special issue that provide more details on particular aspects of the framework or that illustrate the framework's application.

River management often focuses on individual reaches of river networks, aiming to improve their ability to support human needs and those of the river ecosystem. However, the form, sedimentary and vegetation structure, dynamism and behaviour of river reaches depends not only upon natural processes and human interventions within the reach but also within the wider catchment. Furthermore, the response of river reaches to changes in processes and human pressures across the catchment is often delayed. This is because it takes time for the effects of changes (e.g. land cover change, dam construction) to propagate from their initial location across catchments and through river networks to individual river reaches. Thus, understanding of reach scale hydromorphology requires knowledge of processes and human pressures at not only the reach scale but at larger spatial scales including the catchment scale. Since human interventions or pressures at one location and time may induce responses at one or more other locations and times, such knowledge needs to relate to both current and past pressures and processes. Without such a spatial and temporal understanding, management interventions cannot be fully informed and so may not be sustainable and may potentially require significant ongoing maintenance.

In response to this complexity, researchers have developed many spatially-hierarchical frameworks to support better understanding of the functioning of river catchments, networks and corridors. These have been developed with a variety of scientific and management purposes in mind. Several authors have reviewed this topic (e.g. Naiman et al., 1992; Kondolf et al., 2003) and a selection of sixteen examples of hierarchical frameworks, some specifically focussed on hydromorphology, some with a broader ecological focus, are briefly described in Table 1. These examples illustrate a range of different frameworks for developing understanding or assessing river systems by organizing and interpreting information across a hierarchy of spatial scales. Many frameworks incorporate formal classifications of spatial units such as river reaches or segments (i.e. the units are assigned to distinct categories or classes based on specific attributes). Where frameworks incorporate such classifications, they are briefly described in Table 1. The following generalisations can be drawn from the example frameworks listed in Table 1: 
1. Despite its early publication date, the work of Frissell et al. (1986) continues to present the most comprehensive conceptual multi-scale framework for investigating streams and habitats. The spatial units are delineated so that units at smaller spatial scales nest within those at larger spatial scales. The framework incorporates hydromorphological processes and forms and vegetation at all spatial scales in relation to their influence on habitat. Time scales of persistence or adjustment are associated with spatial units at each scale. Indicators of form and process are suggested for spatial units at each scale. The role of the indicators is explained in terms of developing understanding of the functioning of spatial units and the process linkages among units and scales. Although no formal classifications of spatial units are proposed, the way in which indicators could contribute to classification is discussed. All of the methods described in Table 1 consider a hierarchy of spatial units, but the degree to which they develop the other aspects of the conceptual approach proposed by Frissell et al. (1986) varies widely.

2. Many of the frameworks focus entirely on hydromorphological processes and forms that are either directly measured or inferred. This is because interactions between processes and forms control the dynamic morphology or behaviour of rivers and their mosaics of habitats. Hydromorphological processes drive longitudinal and lateral connectivity within river networks and corridors, the assemblage and turnover of physical habitats, and the sedimentary and vegetation structures associated with those habitats.

3. Some frameworks are conceptual, providing a way of thinking about or structuring analyses of river systems, and interpreting their processes, morphology and function (e.g. Frissell et al., 1986; Habersack, 2000; Fausch et al., 2002; Thorp et al., 2006; Beechie et al., 2010; McCluney et al., 2014). Some frameworks are more quantitative, generating one or more indices or classifications of spatial units that support assessment of river systems (e.g. Rosgen, 1994; González del Tánago and García de Jalón, 2004; Merovich et al., 2013; Rinaldi et al., 2013, 2015a). However, some frameworks follow an intermediate course, generating relatively open-ended indices or classes that can be interpreted flexibly (e.g. Brierley and Fryirs, 2005).

4. Time scales and temporal changes are not included in all frameworks, particularly where the framework is proposed as an input to further assessment or analysis (e.g. Snelder and Biggs, 2002, González del Tánago and García de Jalón, 2004). A time scale is included as a dimension of each spatial scale in some approaches (e.g. Habersack, 2000; Dollar et al., 2007), whereas others incorporate historical analyses that track human interventions or changes in units through time at some spatial scales (e.g. Rosgen, 1994; Montgomery and MacDonald, 2002; Brierley and Fryirs, 2005; Beechie et al., 2010; Rinaldi et al., 2013a, 2015). In some cases, theoretical or historical analyses or consideration of specific future scenarios are used to develop space-time understanding that can support management decisionmaking (e.g. Montgomery and Buffington, 1997, 1998; Montgomery and MacDonald, 2002; Benda et al., 2004; Brierley and Fryirs, 2005; McCluney et al., 2014). 
5. Although all frameworks incorporate characteristics that are used to delineate spatial units and may indicate how those units function, many provide specific, well-defined indicators of processes, forms or of the condition of spatial units (e.g. Rosgen, 1994; Montgomery et al., 1997, 1998; Montgomery and MacDonald, 2002; Benda et al., 2004; Brierley and Fryirs, 2005; Merovich et al., 2013; Rinaldi et al., 2013, 2015a). Furthermore, some of the frameworks include indicators of human pressures and their impacts (e.g. Merovich et al., 2013; McCluney et al., 2014; Rinaldi et al., 2013, 2015a).

6. Finally, although most frameworks could be described as incorporating processes to some degree, some methods are particularly process-based, even when processes are inferred from forms and associations rather than being quantified by direct measurements. Frameworks that consider temporal dynamics and trajectories of historical change (see point 4 , above) are particularly effective in developing understanding of processes and the impacts of changed processes cascading through time and across spatial scales.

Although the list of frameworks presented in Table 1 is far from comprehensive, it illustrates that different types of hierarchical framework have been proposed. These previous frameworks have provided a foundation for developing the multi-scale, hierarchical framework for the hydromorphological assessment of European rivers that is described in this paper. This REFORM framework was developed within the REFORM project, which is funded by the European Commission with the aim of supporting sustainable river management and restoration. It has been developed to fit into the context of the European Union's Water Framework Directive (WFD; European Commission, 2000), which constitutes the principal legal instrument for managing and restoring aquatic ecosystems within member states of the European Union, and so it is intended for application by river managers. The following sections of this paper introduce the REFORM framework and describe its key properties; briefly describe the application of the framework; and then introduce this special issue by referring to other papers that provide further details on particular aspects of the framework and its application.

\section{THE REFORM FRAMEWORK}

The REFORM framework is informed by many previous frameworks (Table 1). Those of Frissell et al. (1986), Montgomery and Buffington (1997, 1998), Habersack (2000), Brierley and Fryirs (2005) and Rinaldi et al. (2013) have been particularly influential. Nevertheless, the REFORM framework has several properties that in combination differentiate it from its predecessors and suit it to application by river managers working in the environmental contexts for which it has been developed.

1. Because the aim of the research was to develop a tool for use by river managers, the framework has been kept as simple to apply as was felt possible. It is a hydromorphological framework which includes relevant information on vegetation. 
2. Reflecting the long history of human interventions on European rivers, the framework incorporates human pressures as well as natural processes and forms at all included spatial scales and gives them equal weighting.

3. The framework is open-ended to the extent that European member states can incorporate their own data sets, methods and modelling tools, although specific methods have been proposed and fully-described for consideration by member states. This open-ended nature ensures the framework's relevance to all member states, and thus maximizes the potential for its process-based 'way of thinking' to be widely adopted. It also ensures that elements of the framework methodology can be adapted to local circumstances, reflecting the enormous variety of river environments and data sets found within Europe.

4. The framework includes spatial units at region, catchment, landscape unit, segment, reach, geomorphic unit, hydraulic unit and river element (i.e. patch of sediment, plant stand etc.) scales. However, the core scales are those ranging from catchment to geomorphic unit. Each spatial unit has an indicative temporal scale of persistence / adjustment, but the main temporal element of the framework is a historical analysis of available data sets. A definition of each spatial scale and associated indicative space and time scales are provided in Table 2.

5. The key scale of the framework is the river reach, since this is the scale at which rivers are most often assessed, managed and rehabilitated. A central and unique feature of the REFORM framework is that all reaches are classified into 'river types' using clearly-defined, simple criteria. All other elements of the framework are directed at understanding the naturalness or artificiality of these reaches and their types, the processes to which they are subjected, and their morphodynamic behaviour. This involves assessment of (i) the cascade of processes affecting reaches from catchment to reach scales, (ii) the degree to which reaches display characteristics at reach and finer scales that are indicative of 'natural' function according to their type or of 'artificiality', and (iii) the ways in which reach morphology has changed or behaved through time in response to changes in processes and direct human interventions at catchment to reach scales. To fit with the long history of human pressures on European rivers, and thus the fact that there is no time in the past for which detailed information is available that can be considered to represent pristine conditions, the character of the river in the past is not considered as a 'reference condition' that refers to a 'pristine state'. Instead, the entire space-time analysis assesses the degree to which the morphodynamic behaviour of some river reaches suggest that they are functioning or have functioned in a relatively natural way. This analysis provides process-form information that can inform management of more impacted reaches of otherwise similar type.

6. Recommendations are made on how to delineate spatial units and how processes, forms and human pressures can be represented by indicators. Tables 2 and 3, respectively, provide brief summaries of the properties used for delineation, and the purpose and types of indicators that are estimated. The reach type is the key indicator. 
7. Indicators support the assessment of human pressures, processes, and morphological responses at each spatial scale. They also support the assessment of the past and present behaviour of river reaches and their riparian zones in terms of changes in their form and function in response to changes in processes and human pressures from catchment to reach scales.

8. Space-time understanding of catchments and their river systems is developed from the indicators and provides a basis for estimating potential reach-scale adjustments to future changes across the spatial units (e.g. climate change, land cover change, introduction or removal of channel reinforcement or structures). Such analyses also help to identify whether or not the river type initially defined by simple rules corresponds to the river type that might function most effectively at a given location or whether a different type is more appropriate, so informing the design of any proposed restoration.

Application of the REFORM framework requires a significant data resource. Measurements at the hydraulic unit and river element scales are not widely available. However, collection of such data by purpose-designed field survey contributes to monitoring specific reaches where detail is needed to track changes, particularly following management interventions. Information at all of the other spatial scales can be obtained from national surveys and analyses such as physical habitat surveys, riparian habitat surveys, morphological surveys and hydrological regime assessments (Belletti et al., 2015a); climate, river flow and groundwater data sets; and national scale mapping of, for example, geology, soils and vegetation. Furthermore, many relevant data sets are available at a European scale (Table 4, see also the paper by Bizzi et al., 2015 in this special issue). While contemporary and recent data sets are usually easy to obtain, historical information may be more restricted (for a recent review see Grabowski et al., 2014).

Reflecting the purpose of the application, data availability, and the combination of cost, time and effort that is available, the REFORM framework can be applied in different ways. For catchment assessment and management purposes, the aim should be to sub-divide the entire catchment into a complete set of catchment to reach scale units, and, at a minimum, to include geomorphic units as attributes of each reach. In this way, the assemblage of reach types and their properties can be placed within a catchment and river network context. However, in large catchments, it may not be possible to compile information on a complete set of units for the entire catchment. Under these circumstances, it is necessary to sub-divide the catchment to the scale of its major landscape units, and then isolate representative sub-catchments within each landscape unit where segments and reaches along the main channel and major tributaries can be analysed. In this way, an analysis of the properties of different reach types can be investigated within sub-catchments that are representative of the catchment's landscape units. If the purpose is to focus on a particular reach or segment, perhaps in the context of designing an intervention or rehabilitation, the assessment still needs to focus on spatial units that contain and are immediately upstream of the reach or segment under consideration so that the processes affecting the reach can be investigated. 


\section{OVERVIEW OF THE APPLICATION OF THE REFORM FRAMEWORK}

Application of the framework involves three main stages:

(i) Delineation of the spatial units;

(ii) Assembly of available data sets to Characterise the spatial units so that Indicators of processes, forms and human pressures can be extracted for units across the spatial scales to represent their present and past state;

(iii) Assessment of the present and past character of river reaches (a) to understand how they are affected by processes and human pressures from catchment to segment scales; (b) to understand how these affect river behaviour by driving trajectories of change at the reach scale; and (c) to use the knowledge gained to assess the likely impact of future scenarios on catchment to segment processes and reach scale responses.

Stage (i) Delineation

The boundaries of each spatial unit are delineated using the criteria listed in Table 2, so that each unit at any particular spatial scale is located entirely within a single unit at the next scale. If delineation of geomorphic units, hydraulic units and river elements is required, it must be obtained from field survey. However, sufficient information on geomorphic units is usually available to include them as reach scale indicators during stage (ii). Delineation of other spatial units can be achieved using existing information.

\section{Stage (ii) Characterisation and Indicators}

Once the spatial units are delineated, their properties are characterised using existing data sets. Characterisation involves identifying existing data sets that contain relevant information from which the recommended set of indicators can be extracted. The characterisation process allows incorporation of many local data sets of different types that can help to define a required set of indicators of processes, forms, and human pressures. Some example indicators are listed in Table 3. Further details of the recommended indicators are provided elsewhere in this special issue (González del Tánago et al., 2015a).

Indicators have been devised to represent processes of water and sediment production and delivery at catchment to reach scales, and also human pressures and interventions that may affect water and sediment production and longitudinal continuity through the river system. Indicators also represent the extent and structure of riparian and aquatic vegetation at segment to reach scales and the degree to which these appear to have been impacted by human pressures. At the reach and geomorphic unit scales, indicators refer to flow energy, channel and floodplain dimensions and types, the assemblage of geomorphic units that is present, and the degree to which there are constraints on the lateral continuity of inundation, erosion and deposition of sediment and large wood. 
The key scale is the reach scale and the key indicator at this scale is the river type. Twenty-three river types are defined using three criteria: (1) valley confinement: confined, partly confined, unconfined; (2) planform: straight, sinuous, meandering, braiding, anabranching (defined using specific ranges of values of sinuosity, braiding and anabranching indices); (3) bed material: bedrock, colluvial, boulder, cobble, gravel, sand, silt, clay. River types range from 'confined bedrock' to 'unconfined, sand-silt, anabranching', with reaches with an artificial bed allocated to an 'artificial' type. Information is provided on the typical gradient, stability, size and variability in bed material, and geomorphic units that may be expected if these types are functioning in a natural way. In addition, the river types are associated with floodplain types and the typical floodplain geomorphic units that may be observed if the floodplain is a product of the long term dynamics of the river type. The twenty-three river types were developed from previous geomorphological research (e.g. Schumm, 1985; Knighton and Nanson, 1993; Rosgen, 1994; Nanson and Knighton, 1996; Montgomery and Buffington, 1997; Church, 2006; Fuller et al., 2013; Nanson, 2013) with additional information on geomorphic units in confined and bedrock river reaches obtained from Grant et al. (1990) and Halwas and Church (2002). The ten floodplain types with which the river types are associated, are based on those suggested by Nanson and Croke (1992). This brief summary of the river and floodplain types is fully elaborated elsewhere in this special issue (Rinaldi et al., 2015b).

Most of the indicators (e.g. Table 3) have the potential to change through time, so both their contemporary and past values are estimated wherever possible. Historical analysis of indicators extends back as far as reliable sources of information are available, typically up to 100 years. Ideally, indicators should be evaluated for several time periods in the past to allow a trajectory of change to be tracked. Of course, this may not be feasible, and a longer historical time scale and higher temporal resolution may be achieved for some indicators (e.g. planform) but not for others (e.g. bed elevation).

Stage (iii) Assessments

The indicators that are extracted from the set of past and present characteristics of each spatial unit are integrated to develop an understanding of how and why river reaches have their current properties and also whether these have changed over time and what may have caused such changes. This is tackled in a sequence of four steps that are fully described in the paper by González del Tánago et al. (2015a) which also appears in this special issue. These are briefly outlined below.

First, the current state of individual reaches is assessed. Four main assessments are made:

Hydromorphological function: Starting from the reach type indicator, assessment is based on whether the assemblage of geomorphic units within the channel and floodplain indicate that the reach is functioning as would be expected, and whether the stream power appears to be sufficient to maintain functioning.

Hydromorphological alteration: Given the indicators of human pressures, the degree of disruption of longitudinal and lateral continuity and restriction of bed or bank dynamics within the reach is assessed. 
Riparian corridor function / artificiality: This is assessed using indicators of the size, vegetation age structure, and sources and presence of large wood within the riparian corridor of the reach.

Hydromorphological adjustment: The degree and way in which the reach appears to be adjusting or behaving at present is assessed using indicators of the presence, extent and spatial pattern of relevant geomorphic units, and the sedimentary structure of bed and banks.

Second, past and present indicators at catchment, landscape unit and segment scales are used to estimate past and present water production and delivery, and river flow regime; and also sediment production and delivery from the catchment and through the river network. Comparison of present and past values of these indicators, preferably including several time periods in the past, helps to quantify the degree to which flow and sediment processes have changed through time and the likely causes of the changes (e.g. land cover changes, dam construction, channel reinforcement etc.). Based upon this information, a space-time inventory of changes is constructed, focusing particularly on human alterations that have impacted on flow and sediment processes delivered to river reaches.

Third, reach scale historical indicators are coupled with the contemporary reach scale indicators to reconstruct, as far as is possible, the nature of morphological changes within a reach and the timing of those changes to indicate the changing behaviour of the reach. For example, based on an analysis of historical maps and air photographs, an individual reach may show a trajectory of channel narrowing, widening, lateral migration, or a change in river type through time, or the reach may switch from one adjustment type to another. Vertical changes (e.g. bed incision or aggradation) can also be reconstructed from cross section or longitudinal profile information as well as from the evolution of the stage-discharge relationship at gauging stations (specific-gauge analysis). The causes of any identified changes can then be interpreted from knowledge obtained about changes in flow and sediment processes across the catchment and river network during the second step. Along a river, different river reaches may show different degrees and types of morphological adjustment or different behavioural responses to specific changes in the processes delivered to them. Such differences in adjustment may relate to the reach river type and to human interventions within the reach.

Fourth, potential responses at the reach scale to future scenarios of change can be considered, usually focussing on reaches of different river type within particular segments or landscape units, and using information on the way reaches of this type have adjusted in the past. By basing the assessment of causes and responses to changes in the past on a defined set of indicators, those same indicators and their likely responses to specific future scenarios can be interpreted at all spatial scales, providing a basis for forecasting how reaches of different type may respond to particular types of intervention or process change. Furthermore, where reaches are heavily modified by human interventions, historical analyses of all reaches and consideration of future scenarios may contribute to identifying a more appropriate reach type that could guide rehabilitation or restoration designs. Future trajectories are usually based on a small number of scenarios relevant to the river in question, with the aim of informing management recommendations. Two core scenarios are the likely 
trajectories of adjustment behaviour under (i) the present climate and (ii) likely climate changes (e.g. over the next 50 years) but with no significant change in catchment management. Other scenarios can reflect proposed or likely future changes in river management, land cover, the implementation of particular projects etc.

\section{ELABORATING AND APPLYING THE REFORM FRAMEWORK}

This paper has presented a brief overview of the REFORM framework that has been developed for application by river managers within Europe. It is both flexible and it incorporates many aspects of previous hierarchical frameworks. Therefore, the framework should be applicable to landscapes beyond Europe that have a similar, long history of human pressures, and where a framework for application by river managers is required. Further details of important aspects of the REFORM framework are presented in two other papers in this special issue. The indicators are justified and described and their application is illustrated by González del Tánago et al. (2015a). The paper by Rinaldi et al. (2015b) fully explores three particularly important indicators: the river, floodplain and flow regime types. It also presents a typology of groundwater-surface water interactions that can be linked to the river and floodplain types.

Remotely sensed data sources provide an increasingly important source of information on river catchments, and so the paper by Bizzi et al. (2015) review of this topic to aid users of the REFORM framework to gain information on whatever level of complexity they feel is appropriate. Furthermore, modelling can help to characterise river segments and reaches and can also be used to investigate future scenarios. The paper by Camenen et al. (2015) considers different approaches to modelling the sediment budget of a long segment of a large river, the River Loire, France. Ziliani and Surian (2015) also employ modelling at the segment scale to illustrate how this aids understanding of a trajectory of changes and possible future channel evolution within reaches of the lower course of the Tagliamento River, Italy.

Finally, because of the open-ended nature of the REFORM framework, and the way it can be used to incorporate different local data sets and models to address different management issues, three papers illustrate management-specific applications. These papers illustrate how the framework has helped to diagnose management problems resulting from fine sediment delivery and transfer in a low gradient, temperate, agricultural catchment in southern England (Grabowski and Gurnell, 2015); problems induced by past gravel mining and other disturbances in an Italian river (Belletti et al., 2015b); and problems induced by flow regulation in two rivers in Spain (González del Tánago et al., 2015b).

\section{ACKNOWLEDGMENTS}

The work leading to this paper was funded through the European Union's FP7 programme under Grant Agreement No. 282656 (REFORM). The framework methodology was developed within the 
context of Deliverable D2.1 of the REFORM programme, and all partners who contributed to the development of the four parts of this deliverable are included in the author list of this paper. More details on the REFORM framework can be obtained from part 1 of Deliverable D2.1 (Gurnell et al., 2014), which is downloadable from http://www.reformrivers.eu/results/deliverables

\section{REFERENCES}

Beechie TJ, Sear DA, Olden JD, Pess GR, Buffington JM, Moir H, Roni P, Pollock MM (2010) Process-based Principles for Restoring River Ecosystems. BioScience 60:209-222.

Belletti B, Nardi L, Rinaldi M (2015b) Diagnosing problems induced by past gravel mining and other disturbances in Southern European rivers: the Magra River, Italy. Aquatic Sciences, accepted.

Belletti B, Rinaldi M, Buijse AD, Gurnell AM, Mosselman E (2015a) A review of assessment methods for river hydromorphology. Environmental Earth Sciences 73: 2079-2100.

Benda L, Leroy Poff N, Miller D, Dunne T, Reeves G, Pess G, Pollock M (2004) The network dynamics hypothesis: How Channel Networks Structure Riverine Habitats. BioScience 54: 413427.

Bizzi S, van de Bund W, Demarchi L, Weissteiner C, Grabowski RC (2015) The use of Remote Sensing for characterising hydromorphological properties of European rivers. Aquatic Sciences, First online, DOI: 10.1007/s00027-015-0430-7.

Brierley GJ, Fryirs K (2000) River Styles, a geomorphic approach to catchment characterization: Implications for river rehabilitation in Bega catchment, New South Wales, Australia. Environmental Management 25: 661-679.

Brierley GJ, Fryirs KA (2005) Geomorphology and River management: Applications of the River Styles Framework. Blackwell, Malden USA, Oxford UK, Carlton Australia.

Camenen B, Latapie A, Paquier A., Rodriques S, Grabowski RC, Solari L. (2015) On the estimation of the bed-material transport and budget along a river segment: application to the Middle Loire River, France. Aquatic Sciences, accepted.

Church M. (2006) Bed material transport and the morphology of alluvial river channels. Annu. Rev. Earth Planet. Sci. 34: 325-354.

Dollar ESJ, James CS, Rogers KH, Thoms MC (2007) A framework for interdisciplinary understanding of rivers as ecosystems. Geomorphology 89: 147-162.

European Commission. 2000. Directive 2000/60/EC of the European Parliament and of the Council of 23 October 2000 establishing a framework for Community action in the field of water policy. Official Journal of the European Communities L327:1-72. 
Fausch KD, Torgersen CE, Baxter CV, Li HW. (2002) Landscapes to Riverscapes: Bridging the Gap between Research and Conservation of Stream Fishes. BioScience 52: 483-498.

Frissell CA, Liss WJ, Warren CE, Hurley MD (1986) A hierarchical framework for stream habitat classification: Viewing streams in a watershed context. Environmental Management 10: 199214.

Fuller IC, Reid HE, Brierley GJ. (2013) Methods in Geomorphology: Investigating River Channel Form. In: J.F. Shroder (ed) Treatise on Geomorphology, Academic Press, San Diego, pp 7391.

González del Tánago M, García de Jalón D. (2004) Hierarchical Classification of Rivers: A proposal for eco-geomorphic characterization of Spanish rivers within the European Water Frame Directive. In: García de Jalón D, Vizcaíno P (eds.) Aquatic Habitats, Analysis and Restoration, Fifth International Symposium on Ecohydraulics, IAHR Congress Proceedings, Madrid, Spain, 205-211.

González del Tánago M, Belletti B, Gurnell AM (2015a) Indicators of river system character and dynamics, past and present: understanding the causes and solutions to river management problems. Aquatic Sciences, accepted.

González del Tánago M, Martínez-Fernández V, García de Jalón D (2015b) Diagnosing problems produced by flow regulation in Southern European rivers: The Porma and Curueño Rivers (Duero Basin, NW Spain). Aquatic Sciences, First online, DOI: 10.1007/s00027-015-0428-1.

Grabowski RC, Surian N, Gurnell AM (2014) Characterizing geomorphological change to support sustainable river restoration and management. WIREs Water, doi:10.1002/wat2.1037.

Grabowski RC, Gurnell AM (2015) Diagnosing problems of fine sediment delivery and transfer in lowland, Northwest European catchments: The Frome catchment, southern England. Aquatic Sciences, First online, DOI: 10.1007/s00027-015-0426-3.

Grant GE, Swanson FJ, Wolman MG (1990) Pattern and origin of stepped-bed morphology in high gradient streams, Western Cascades, Oregon. Bulletin of the Geological Society of America, 102: 340-354.

Gurnell AM, Belletti B, Bizzi S, Blamauer B, Braca G, Buijse T, Bussettini M, Camenen B, Comiti F, Demarchi L, García de Jalón D, González del Tánago M, Grabowski RC, Gunn IDM, Habersack H, Hendriks D, Henshaw A, Klösch M, Lastoria B, Latapie A, Marcinkowski P, Martínez-Fernández V, Mosselman E, Mountford JO, Nardi L, Okruszko T, O’Hare MT, Palma M, Percopo C, Rinaldi M, Surian N, Weissteiner C, Ziliani L (2014) A hierarchical multi-scale framework and indicators of hydromorphological processes and forms. Deliverable 2.1, a report in four parts of REFORM (REstoring rivers FOR effective catchment Management), a Collaborative project (large-scale integrating project) funded by the European Commission 
within the $7^{\text {th }}$ Framework Programme under Grant Agreement 282656. Downloadable from http://www.reformrivers.eu/results/deliverables

Habersack HM (2000) The river-scaling concept (RSC): a basis for ecological assessments. Hydrobiologia 422/423: 49-60.

Halwas KL, Church M. (2002) Channel units in small, high gradient streams on Vancouver Island, British Columbia. Geomorphology 43: 243-256.

Knighton AD, Nanson GC. (1993) Anastomosis and the continuum of channel pattern. Earth Surface Processes and Landforms 18(7): 613-625.

Kondolf GM, Montgomery DR, Piégay H, Schmitt L (2003) Geomorphic classification of rivers and streams. In: Kondolf GM, Piégay H (eds) Tools in fluvial geomorphology, Wiley, Chichester, UK, pp 171-204.

McCluney KE, Poff NL, Palmer MA, Thorp JH, Poole GC, Williams BS, Williams MR, Baron JS. (2014) Riverine macrosystems ecology: sensitivity, resistance, and resilience of whole river basins with human alterations. Frontiers in Ecology and the Environment 12: 48-58.

Merovich GT, Petty JT, Strager MP, Fulton JB. (2013) Hierarchical classification of stream condition: a house-neighborhood framework for establishing conservation priorities in complex riverscapes, Freshwater Science 32(3): 874-891, doi:10.1899/12-082.1.

Montgomery DR, Buffington JM. (1997) Channel reach morphology in mountain drainage basins. Geological Society of America Bulletin 109: 596-611.

Montgomery DR, Buffington JM (1998) Channel processes, classification and response potential. In: Naiman RJ, Bilby RE (eds) River ecology and management, Springer-Verlag Inc., New York, pp 13-42.

Montgomery DR, MacDonald LH. (2002) Diagnostic approach to stream channel assessment and monitoring. Journal of the American Water Resources Association 38: 1-16.

Naiman RJ, Lonzarich DG, Beechie TJ, Ralph SC (1992) General principles of classification and the assessment of conservation potential in rivers. In: Boon PJ, Calow P, Petts GE (eds) River Conservation and Management, John Wiley and Sons, Chichester, UK, pp 93-123.

Nanson GC. (2013) Anabranching and Anastomosing Rivers. In: John F. Shroder (ed) Treatise on Geomorphology, Volume 9, Academic Press, San Diego, pp 330-345.

Nanson GC, Croke JC. (1992) A genetic classification of floodplains. Geomorphology 4(6): 459-486.

Nanson GC, Knighton AD. (1996) Anabranching rivers: their causes, character and classification. Earth Surface Processes and Landforms 21(3): 217-239. 
Rinaldi M, Gurnell AM, González del Tánago M, Bussettini M, Hendriks D (2015b) Classification and characterization of river morphology and hydrology to support management and restoration. Aquatic Sciences, accepted.

Rinaldi M, Surian N, Comiti F, Bussettini M (2013) A method for the assessment and analysis of the hydromorphological condition of Italian streams: The Morphological Quality Index (MQI). Geomorphology 180-181: 96-108.

Rinaldi M, Surian N, Comiti F, Bussettini M (2015a) A methodological framework for hydromorphological assessment, analysis and monitoring (IDRAIM) aimed at promoting integrate driver management. Geomorphology, doi:10.1016/j.geomorph.2015.05.010.

Rosgen D (1994) A classification of natural rivers. Catena 22:169-199.

Schumm SA. (1985) Patterns of alluvial rivers. Annual Reviews of Earth and Planetary Science 13: 527.

Snelder TH, Biggs BJF (2002) Multiscale river environment classification for water resources management. Journal of the American Water Resources Association 38: 1225-1239.

Thorp JH, Thoms MC, Delong MD (2006) The riverine ecosystem synthesis: biocomplexity in river networks across space and time. River Research and Applications 22: 123-147.

Ziliani L, Surian N (2015) Reconstructing temporal changes and prediction of channel evolution in a large Alpine river: the Tagliamento River, Italy. Aquatic Sciences, First online, DOI: 10.1007/s00027-015-0431-6. 
Table 1. Examples of spatially-hierarchical frameworks to support better understanding of the functioning of river catchments, corridors and networks.

\begin{tabular}{|c|c|c|c|c|c|c|}
\hline Source & Aims & Spatial Scales & $\begin{array}{l}\text { Historical Analysis, } \\
\text { Time Scales }\end{array}$ & $\begin{array}{l}\text { Process / Form / Intervention } \\
\text { Indicators }\end{array}$ & Classifications $^{1}$ & Scenarios \\
\hline $\begin{array}{l}\text { Frissell et } \\
\text { al. (1986) }\end{array}$ & $\begin{array}{l}\text { Classification of streams and } \\
\text { habitats to support } \\
\text { monitoring, determine local } \\
\text { impacts of land use practices, } \\
\text { generalise from site data, } \\
\text { assess basin-wide, } \\
\text { cumulative impacts of human } \\
\text { activities. }\end{array}$ & $\begin{array}{l}\text { WATERSHED SYSTEM } \\
\text { STREAM SYSTEM } \\
\text { SEGMENT SYSTEM } \\
\text { REACH SYSTEM } \\
\text { 'POOL-RIFFLE' } \\
\text { SYSTEM } \\
\text { MICROHABITAT } \\
\text { SYSTEM }\end{array}$ & $\begin{array}{l}\text { Time scale of potential } \\
\text { continuous persistence } \\
\text { for each spatial scale. }\end{array}$ & $\begin{array}{l}\text { Characteristic variables proposed, } \\
\text { many of which are sufficiently specific } \\
\text { to be indicators. } \\
\text { WATERSHED: geology, topography, } \\
\text { soils, climate, biota, culture. } \\
\text { STREAM SYSTEM: long profile } \\
\text { slope, shape, network structure. } \\
\text { SEGMENT: channel floor lithology, } \\
\text { down-valley slope, position in } \\
\text { network, valley side slope, potential } \\
\text { climax vegetation, soils } \\
\text { REACH: bedrock relief, down-valley } \\
\text { slope, morphogenetic form or } \\
\text { process, channel pattern, local side } \\
\text { slopes, floodplain, bank composition, } \\
\text { riparian vegetation } \\
\text { POOL-RIFFLE: bed topography, } \\
\text { water surface slope, morphogenetic } \\
\text { form or process, immovable } \\
\text { substrates, bank configuration. } \\
\text { MICROHABITAT: under- and over- } \\
\text { lying substrate, water depth, velocity, } \\
\text { overhanging cover. }\end{array}$ & $\begin{array}{l}\text { No specific classifications proposed } \\
\text { but open-ended criteria (see } \\
\text { indicators) are provided for } \\
\text { delineating and characterising } \\
\text { stream, segment, reach, 'pool-riffle', } \\
\text { microhabitat types to underpin } \\
\text { classification of Watersheds, } \\
\text { Streams, Segments, Reaches, 'Pool- } \\
\text { riffles', Microhabitats to indicate how } \\
\text { smaller units of particular types } \\
\text { contribute to larger units in a nested } \\
\text { way, with temporal dynamics } \\
\text { appropriate to the spatial scale. }\end{array}$ & $\begin{array}{l}\text { Not explicitly considered, but } \\
\text { relevant topics discussed. }\end{array}$ \\
\hline $\begin{array}{l}\text { Rosgen } \\
\text { (1994) }\end{array}$ & $\begin{array}{l}\text { Classification system for } \\
\text { natural rivers suitable for } \\
\text { engineering, fish habitat } \\
\text { enhancement and water } \\
\text { resource management } \\
\text { applications. }\end{array}$ & $\begin{array}{l}\text { LEVEL I: GEOMORPHIC } \\
\text { CHARACTERISATION } \\
\text { (approximates segment } \\
\text { scale) } \\
\text { LEVEL II: } \\
\text { MORPHOLOGICAL } \\
\text { DESCRIPTION } \\
\text { (approximates reach to } \\
\text { geomorphic unit scale) }\end{array}$ & $\begin{array}{l}\text { Stream type changes } \\
\text { through time are } \\
\text { established from } \\
\text { historical maps and } \\
\text { aerial photographs. }\end{array}$ & $\begin{array}{l}\text { Stream type is the only true indicator, } \\
\text { although it is defined by value ranges } \\
\text { of indicative stream properties, and is } \\
\text { the output of a classification } \\
\text { procedure (see classification). } \\
\text { Processes and sensitivity are inferred } \\
\text { from stream types (sensitivity to } \\
\text { disturbance, recovery potential, } \\
\text { sediment supply, stream bank erosion } \\
\text { potential, vegetation influence). }\end{array}$ & $\begin{array}{l}\text { STREAM TYPES are defined by } \\
\text { value ranges of stream } \\
\text { characteristics: } \\
9 \text { LEVEL I TYPES: slope, valley- } \\
\text { channel cross section (entrenchment, } \\
\text { w/d), channel planform (sinuosity). } \\
42 \text { LEVEL II TYPES: subdivision of } \\
\text { level I types using channel material } \\
\text { types and channel slope ranges. }\end{array}$ & $\begin{array}{l}\text { Not explicitly considered, but } \\
\text { some discussion of relevant } \\
\text { themes. }\end{array}$ \\
\hline $\begin{array}{l}\text { Montgomery } \\
\text { and } \\
\text { Buffington } \\
\text { (1997, } \\
1998)\end{array}$ & $\begin{array}{l}\text { Geomorphological channel } \\
\text { classifications and their use } \\
\text { for systematizing channel } \\
\text { morphology and physical } \\
\text { processes for assessing } \\
\text { physical channel condition } \\
\text { and response potential. }\end{array}$ & $\begin{array}{l}\text { REGION (geomorphic } \\
\text { province) } \\
\text { CATCHMENT (climate, } \\
\text { geology, land use) } \\
\text { VALLEY SEGMENT } \\
\text { CHANNEL REACH } \\
\text { CHANNEL UNIT }\end{array}$ & $\begin{array}{l}\text { Examples of historical } \\
\text { change presented, but } \\
\text { process change } \\
\text { scenarios considered } \\
\text { rather than a formal } \\
\text { historical analyses. }\end{array}$ & $\begin{array}{l}\text { LOCAL: } \\
\text { valley bottom slope, confinement, } \\
\text { entrenchment, riparian vegetation; } \\
\text { overbank deposits; active channel - } \\
\text { pattern; bank condition; bars, pools, } \\
\text { bed material. }\end{array}$ & $\begin{array}{l}\text { 3 VALLEY SEGMENT TYPES: } \\
\text { Colluvial, Bedrock, Alluvial } \\
9 \text { CHANNEL TYPES: Colluvial, } \\
\text { Bedrock, Cascade, Step-pool, Plane- } \\
\text { bed, Pool-riffle, Dune-ripple, Forced } \\
\text { step-pool, Forced pool-riffle. }\end{array}$ & $\begin{array}{l}\text { Changes in riparian } \\
\text { vegetation and delivery of } \\
\text { large wood, discharge, and } \\
\text { sediment (including passage } \\
\text { of sediment waves). }\end{array}$ \\
\hline
\end{tabular}




\begin{tabular}{|c|c|c|c|c|c|c|}
\hline Source & Aims & Spatial Scales & $\begin{array}{l}\text { Historical Analysis, } \\
\text { Time Scales }\end{array}$ & $\begin{array}{l}\text { Process / Form / Intervention } \\
\text { Indicators }\end{array}$ & Classifications & Scenarios \\
\hline $\begin{array}{l}\text { Habersack } \\
(2000)\end{array}$ & $\begin{array}{l}\text { River-scaling approach to the } \\
\text { assessment of abiotic and } \\
\text { biotic components of rivers. }\end{array}$ & $\begin{array}{l}\text { REGION-CONTINENT } \\
\text { CATCHMENT } \\
\text { SECTION } \\
\text { LOCAL } \\
\text { POINT }\end{array}$ & $\begin{array}{l}\text { Provides typical } \\
\text { timescales for } \\
\text { adjustments in abiotic } \\
\text { and biotic processes and } \\
\text { patterns. Infers / models } \\
\text { causes and effects } \\
\text { through downscaling and } \\
\text { upscaling analyses. }\end{array}$ & $\begin{array}{l}\text { REGION-CONTINENT: geology, } \\
\text { tectonics, hydrology. } \\
\text { CATCHMENT: size, network, erosion } \\
\text { potential. } \\
\text { SECTION: slope, planform, sediment } \\
\text { regime. } \\
\text { LOCAL: bed and bank forms and } \\
\text { inferred processes. } \\
\text { POINT: substrate calibre, variability, } \\
\text { sorting, flow velocity, shear stress } \\
\text { etc.. }\end{array}$ & $\begin{array}{l}\text { No specific classifications but open- } \\
\text { ended criteria are provided for the } \\
\text { physical characterisation of each } \\
\text { spatial scale unit and for the } \\
\text { interpretation of linkages by } \\
\text { downscaling and upscaling. }\end{array}$ & Not explicitly considered. \\
\hline $\begin{array}{l}\text { Fausch et } \\
\text { al. (2002) }\end{array}$ & $\begin{array}{l}\text { Conceptual framework for } \\
\text { studying and managing lotic } \\
\text { fishes and their habitats in the } \\
\text { context of riverscapes, which } \\
\text { explicitly embraces the } \\
\text { continuous, hierarchical, and } \\
\text { heterogeneous nature of } \\
\text { these linear aquatic habitats. }\end{array}$ & $\begin{array}{l}\text { BASIN } \\
\text { SEGMENT } \\
\text { REACH } \\
\text { CHANNEL UNIT } \\
\text { MICRO-HABITAT }\end{array}$ & $\begin{array}{l}\text { No explicit historical } \\
\text { component, although } \\
\text { spatio-temporal changes } \\
\text { are discussed. }\end{array}$ & $\begin{array}{l}\text { Broad recommendations reflecting } 5 \\
\text { principles: } \\
\text { 1. Choose appropriate scales, think / } \\
\text { work at multiple scales. } \\
\text { 2. Processes interact across scales - } \\
\text { embrace this complexity. } \\
\text { 3. Unique features (e.g. discrete } \\
\text { habitat features or rare events) can } \\
\text { have over-riding effects. } \\
\text { 4. Unintended consequences of } \\
\text { habitat degradation occur in all } \\
\text { directions. } \\
\text { 5. Match observations and predictions } \\
\text { to scales at which managers may } \\
\text { effect change. }\end{array}$ & No explicit classifications. & $\begin{array}{l}\text { Scenarios not explicitly } \\
\text { considered as part of the } \\
\text { framework, but discussion of } \\
\text { emerging challenges } \\
\text { encompasses potential future } \\
\text { changes. }\end{array}$ \\
\hline $\begin{array}{l}\text { Montgomery } \\
\text { and } \\
\text { MacDonald } \\
(2002)\end{array}$ & $\begin{array}{l}\text { Conceptual framework for } \\
\text { diagnosing channel condition, } \\
\text { evaluating channel response, } \\
\text { and developing channel } \\
\text { monitoring programs. }\end{array}$ & $\begin{array}{l}\text { REGION (biogeographic } \\
\text { context), } \\
\text { CATCHMENT } \\
\text { LOCAL ( valley and } \\
\text { channel). }\end{array}$ & $\begin{array}{l}\text { CATCHMENT: changes } \\
\text { in water, sediment, } \\
\text { riparian vegetation, } \\
\text { wood inputs. } \\
\text { LOCAL: changes in } \\
\text { riparian vegetation, } \\
\text { channel dimensions, } \\
\text { pattern, features, bed } \\
\text { material. }\end{array}$ & $\begin{array}{l}\text { CATCHMENT: proximity to water, } \\
\text { sediment, wood sources. } \\
\text { LOCAL: valley bottom: slope, } \\
\text { confinement, entrenchment, riparian } \\
\text { vegetation, overbank deposits; active } \\
\text { channel: pattern, bank condition, bars, } \\
\text { pools, bed material. }\end{array}$ & $\begin{array}{l}5 \text { CHANNEL TYPES: Cascade, Step- } \\
\text { pool, Plane-bed, Pool-riffle, Dune- } \\
\text { ripple (differences in energy } \\
\text { dissipation and relative transport } \\
\text { capacity). }\end{array}$ & $\begin{array}{l}\text { Chronic increases in: supply } \\
\text { of coarse sediment, supply of } \\
\text { fine sediment, peak flow } \\
\text { magnitude-frequency. }\end{array}$ \\
\hline
\end{tabular}




\begin{tabular}{|c|c|c|c|c|c|c|}
\hline Source & Aims & Spatial Scales & $\begin{array}{l}\text { Historical Analysis, } \\
\text { Time Scales }\end{array}$ & $\begin{array}{l}\text { Process / Form / Intervention } \\
\text { Indicators }\end{array}$ & Classifications & Scenarios \\
\hline $\begin{array}{l}\text { Snelder and } \\
\text { Biggs } \\
(2002)\end{array}$ & $\begin{array}{l}\text { River environment } \\
\text { classification aims to provide } \\
\text { a multi-scale spatial } \\
\text { framework for river } \\
\text { management }\end{array}$ & $\begin{array}{l}\text { MACRO } \\
\text { MESO } \\
\text { MICRO }\end{array}$ & No historical component. & $\begin{array}{l}\text { In application to New Zealand } \\
\text { CLIMATE: mean annual precipitation, } \\
\text { temperature, potential } \\
\text { evapotranspiration. } \\
\text { SOURCE OF FLOW: rainfall volume } \\
\text { in elevation categories, lake influence } \\
\text { index. } \\
\text { GEOLOGY: proportions of each } \\
\text { geological category in reach } \\
\text { catchment area. } \\
\text { LANDCOVER: proportion of each } \\
\text { land cover category in reach } \\
\text { catchment area. } \\
\text { NETWORK POSITION: stream order. } \\
\text { VALLEY LANDFORM: slope. }\end{array}$ & $\begin{array}{l}\text { REACHES ARE CLASSIFIED based } \\
\text { on a spatial hierarchy of controlling } \\
\text { factors: } \\
\text { MACRO-MESO Watershed controls } \\
\text { on water and sediment supply. } \\
\text { Climate, Source of Flow, Geology, } \\
\text { Land cover. } \\
\text { MICRO Local scale interactions } \\
\text { between watershed controls and } \\
\text { topographic factors. Network position, } \\
\text { Valley landform. }\end{array}$ & Not considered. \\
\hline $\begin{array}{l}\text { Benda et al. } \\
(2004)\end{array}$ & $\begin{array}{l}\text { Geomorphic framework to } \\
\text { develop testable predictions } \\
\text { about how the spatial } \\
\text { arrangement of tributaries in } \\
\text { a river network interacts with } \\
\text { stochastic watershed } \\
\text { processes to influence spatio- } \\
\text { temporal patterns of habitat } \\
\text { heterogeneity. }\end{array}$ & $\begin{array}{l}\text { BASIN } \\
\text { SUB-BASIN } \\
\text { NETWORK } \\
\text { CONFLUENCE }\end{array}$ & $\begin{array}{l}\text { No historical component, } \\
\text { although theoretical } \\
\text { temporal changes are } \\
\text { fundamental to the } \\
\text { framework. }\end{array}$ & $\begin{array}{l}\text { Seven structural indicators of river } \\
\text { networks: } \\
\text { BASIN: } 1 \text {. size, } 2 \text {. shape. } \\
\text { SUB BASIN: } 3 \text {. network configuration, } \\
\text { 4. size difference between tributary } \\
\text { and main stem. } \\
\text { NETWORK: } 5 \text {. drainage density; } 6 \text {. } \\
\text { confluence density. } \\
\text { CONFLUENCE: } 7 \text {. network geometry } \\
\text { (confluence angle, distance between } \\
\text { tributaries). }\end{array}$ & $\begin{array}{l}\text { Classification is not part of this } \\
\text { framework. }\end{array}$ & $\begin{array}{l}\text { Consider theoretically how } \\
\text { stochastic watershed } \\
\text { disturbances (e.g. floods, fire, } \\
\text { storms) impose temporal } \\
\text { heterogeneity on confluence } \\
\text { effects in a predictable } \\
\text { fashion that reflects controls } \\
\text { exerted by the network } \\
\text { structure. }\end{array}$ \\
\hline $\begin{array}{l}\text { González } \\
\text { del Tánago } \\
\text { and García } \\
\text { de Jalón } \\
\text { (2004) }\end{array}$ & $\begin{array}{l}\text { Hierarchical classification } \\
\text { system for application to } \\
\text { Spanish rivers. }\end{array}$ & $\begin{array}{l}\text { ECOREGION } \\
\text { WATERSHED } \\
\text { SEGMENT } \\
\text { REACH }\end{array}$ & No historical component. & No explicitly stated indicators. & $\begin{array}{l}\text { SPATIAL UNITS CLASSIFIED AT } \\
\text { ALL FOUR CONSIDERED SCALES } \\
\text { using pre-existing methods, in some } \\
\text { cases adapted or combined. }\end{array}$ & Not considered. \\
\hline $\begin{array}{l}\text { Brierley and } \\
\text { Fryirs } \\
(2000, \\
2005)\end{array}$ & $\begin{array}{l}\text { The River Styles Framework } \\
\text { provides a coherent, } \\
\text { catchment-wide template for } \\
\text { river management. }\end{array}$ & $\begin{array}{l}\text { CATCHMENT } \\
\text { LANDSCAPE UNIT } \\
\text { REACH } \\
\text { GEOMORPHIC UNITS } \\
\text { HYDRAULIC UNITS }\end{array}$ & $\begin{array}{l}\text { An evolutionary } \\
\text { sequence is constructed } \\
\text { for each river (reach) } \\
\text { style using field evidence } \\
\text { and information from } \\
\text { historical sources. This } \\
\text { is interpreted using } \\
\text { historical evidence of } \\
\text { catchment to reach scale } \\
\text { changes in geomorphic } \\
\text { linkages and human } \\
\text { interventions. }\end{array}$ & $\begin{array}{l}\text { Process controls are inferred from } \\
\text { downstream sequences of river } \\
\text { (reach) styles in the context of } \\
\text { catchment area, valley width and } \\
\text { slope, unit stream power for specific } \\
\text { flood events, and an assessment of } \\
\text { whether each is sediment supply or } \\
\text { transport limited. }\end{array}$ & $\begin{array}{l}\text { No explicit classifications provided. A } \\
\text { river styles tree is developed for a } \\
\text { catchment where each reach style is } \\
\text { related to its valley setting, planform, } \\
\text { bed material texture and geomorphic } \\
\text { units. }\end{array}$ & $\begin{array}{l}\text { Guidance is provided for } \\
\text { assessing reach reference } \\
\text { conditions, current condition, } \\
\text { sensitivity and recovery } \\
\text { potential. These are used to } \\
\text { assess the impact of various } \\
\text { scenarios on river style and } \\
\text { condition change. }\end{array}$ \\
\hline
\end{tabular}




\begin{tabular}{|c|c|c|c|c|c|c|}
\hline Source & Aims & Spatial Scales & $\begin{array}{l}\text { Historical Analysis, } \\
\text { Time Scales }\end{array}$ & $\begin{array}{l}\text { Process / Form / Intervention } \\
\text { Indicators }\end{array}$ & Classifications & Scenarios \\
\hline $\begin{array}{l}\text { Thorp et al. } \\
(2006)\end{array}$ & $\begin{array}{l}\text { The Riverine Ecosystem } \\
\text { Synthesis is a framework for } \\
\text { understanding both broad, } \\
\text { often discontinuous patterns } \\
\text { along longitudinal and lateral } \\
\text { dimensions of river networks } \\
\text { and local ecological patterns } \\
\text { across various temporal and } \\
\text { smaller spatial } \\
\text { scales. }\end{array}$ & $\begin{array}{l}\text { CATCHMENT / } \\
\text { ECOREGION } \\
\text { RIVER NETWORK } \\
\text { FUNCTIONAL } \\
\text { PROCESS ZONE } \\
\text { HYDROGEOMORPHIC } \\
\text { PATCH TYPES } \\
\text { ABIOTIC AND BIOTIC } \\
\text { (MICROHABITAT) } \\
\text { PATCHES }\end{array}$ & $\begin{array}{l}\text { No explicit historical } \\
\text { component. Time scale } \\
\text { is restricted to ecological } \\
\text { time frames relevant to } \\
\text { community regulation } \\
\text { and ecosystem } \\
\text { processes. }\end{array}$ & $\begin{array}{l}\text { No explicit process indicators but the } \\
\text { following are provided: } \\
\text { (i) a list of mechanisms influencing } \\
\text { different abiotic and biotic patch } \\
\text { types. } \\
\text { (ii) a list of tenets / hypotheses } \\
\text { relating species diversity, density, } \\
\text { distribution; community composition; } \\
\text { and biocomplexity to the types, } \\
\text { mosaics, dynamics and controlling } \\
\text { processes of functional processes } \\
\text { zones and their contained patches. }\end{array}$ & $\begin{array}{l}\text { No explicit classifications but } \\
\text { conceptualises some downstream } \\
\text { patterning in the character of } \\
\text { functional process and their contained } \\
\text { hydrogeomorphic patches and abiotic } \\
\text { / biotic sub-patches through river } \\
\text { networks. }\end{array}$ & $\begin{array}{l}\text { None explicitly considered } \\
\text { although relevant topics are } \\
\text { discussed. }\end{array}$ \\
\hline $\begin{array}{l}\text { Dollar et al. } \\
\text { (2007) }\end{array}$ & $\begin{array}{l}\text { A framework for the } \\
\text { interdisciplinary study and } \\
\text { management of river } \\
\text { ecosystems which } \\
\text { incorporates parallel } \\
\text { hierarchies in the } \\
\text { geomorphology, hydrology } \\
\text { and ecology of a river with } \\
\text { different organizational } \\
\text { elements and levels of } \\
\text { organization for each. }\end{array}$ & $\begin{array}{l}\text { Geomorphological } \\
\text { spatial hierarchy: } \\
\text { GEOMORPHIC } \\
\text { PROVINCE, DRAINAGE } \\
\text { BASIN, MACRO- } \\
\text { REACH, CHANNEL } \\
\text { TYPE, PARTICLE } \\
\text { Ecological spatial } \\
\text { hierarchy: LANDSCAPE, } \\
\text { ECOSYSTEM, } \\
\text { COMMUNITY, } \\
\text { SPECIES, ORGANISM } \\
\text { Hydrological hierarchy: } \\
\text { OCCURRENCE, } \\
\text { VOLUME, DISCHARGE, } \\
\text { VELOCITY, } \\
\text { TURBULENCE }\end{array}$ & $\begin{array}{l}\text { No explicit historical } \\
\text { component. However, } \\
\text { timescales of } \\
\text { persistence / stability / } \\
\text { adjustment are proposed } \\
\text { for each hierarchical } \\
\text { element. }\end{array}$ & $\begin{array}{l}\text { Processes at relevant timescales are } \\
\text { proposed for each spatial scale. In a } \\
\text { South African application of the } \\
\text { hydrology-geomorphology } \\
\text { subsystems: } \\
\text { GEOMORPHIC PROVINCE / BASIN: } \\
\text { tectonic, climate change, base level } \\
\text { change, weathering and erosion. } \\
\text { MACRO-REACH: climate variability, } \\
\text { weathering and erosion. } \\
\text { CHANNEL TYPE: sediment transport, } \\
\text { deposition, vegetation stabilisation. } \\
\text { GEOMRPHIC UNIT: flow-sediment- } \\
\text { vegetation feedbacks, sediment } \\
\text { transport, deposition, entrainment. }\end{array}$ & No explicit classifications & $\begin{array}{l}\text { Multi-level flow chain models } \\
\text { are constructed to assess the } \\
\text { outcomes of specific changes } \\
\text { in, for example, the flow } \\
\text { regime. }\end{array}$ \\
\hline $\begin{array}{l}\text { Beechie et } \\
\text { al. }(2010)\end{array}$ & $\begin{array}{l}\text { An open-ended approach to } \\
\text { process-based restoration } \\
\text { acknowledging that } \\
\text { ecosystem conditions at any } \\
\text { site are governed by } \\
\text { hierarchical regional, } \\
\text { watershed, and reach-scale } \\
\text { processes controlling } \\
\text { hydrologic and sediment } \\
\text { regimes; floodplain and } \\
\text { aquatic habitat dynamics; and } \\
\text { riparian and aquatic biota. }\end{array}$ & $\begin{array}{l}\text { REGION / LANDSCAPE } \\
\text { WATERSHED } \\
\text { REACH }\end{array}$ & $\begin{array}{l}\text { Compares historical and } \\
\text { present land use at } \\
\text { watershed scale, habitat } \\
\text { conditions and biota at } \\
\text { reach scale in order to } \\
\text { guide appropriate } \\
\text { restoration actions. }\end{array}$ & $\begin{array}{l}\text { Incorporates indicators of driving } \\
\text { processes: } \\
\text { REGION / LANDSCAPE: tectonics, } \\
\text { erosion. } \\
\text { CATCHMENT: runoff processes, } \\
\text { erosion - sediment supply, discharge. } \\
\text { REACH: riparian processes, channel- } \\
\text { floodplain interactions. }\end{array}$ & No explicit classifications & $\begin{array}{l}\text { Presents restoration } \\
\text { principles rather than } \\
\text { scenario responses: } \\
\text { 1. Target root causes of } \\
\text { habitat and ecosystem } \\
\text { change. } \\
\text { 2. Tailor restoration actions to } \\
\text { local potential. } \\
\text { 3. Match scale of restoration } \\
\text { to scale of physical and } \\
\text { biological processes. } \\
\text { 4. Be explicit about expected } \\
\text { outcomes and recovery time. }\end{array}$ \\
\hline
\end{tabular}




\begin{tabular}{|c|c|c|c|c|c|c|}
\hline Source & Aims & Spatial Scales & $\begin{array}{l}\text { Historical Analysis, } \\
\text { Time Scales }\end{array}$ & $\begin{array}{l}\text { Process / Form / Intervention } \\
\text { Indicators }\end{array}$ & Classifications & Scenarios \\
\hline $\begin{array}{l}\text { Merovich et } \\
\text { al. (2013) }\end{array}$ & $\begin{array}{l}\text { Multiscale approach for } \\
\text { establishing stream } \\
\text { conservation priorities in } \\
\text { active coal-mining regions, } \\
\text { based on relating landscape } \\
\text { variables to water chemistry } \\
\text { and ecological condition at } \\
\text { the segment scale. }\end{array}$ & $\begin{array}{l}\text { WATERSHED } \\
\text { (COMMUNITY) } \\
\text { SUB-WATERSHED } \\
\text { (NEIGHBOURHOOD) } \\
\text { SEGMENT } \\
\text { WATERSHED (HOUSE) }\end{array}$ & No historical analysis. & $\begin{array}{l}\text { Uses combined ICI results for } \\
\text { watershed - sub-watershed - } \\
\text { segment classifications to identify and } \\
\text { prioritise stream restoration and } \\
\text { protection priorities at the segment } \\
\text { scale. ICI results incorporate } \\
\text { landscape indicators of human } \\
\text { interventions (mining, land cover) and } \\
\text { natural processes (drainage area, } \\
\text { geology, topography). }\end{array}$ & $\begin{array}{l}\text { CLASSIFIES SEGMENTS according } \\
\text { to their conditions (Integrated } \\
\text { Condition Index, ICI) based on a } \\
\text { statistical analysis of segment water } \\
\text { quality and ecological conditions and } \\
\text { their landscape properties. Segment } \\
\text { level conditions (ICI) are } \\
\text { amalgamated through a weighted } \\
\text { procedure, to sub-watershed } \\
\text { (neighbourhood) and watershed } \\
\text { (community) scales. }\end{array}$ & Not explicitly considered. \\
\hline $\begin{array}{l}\text { McCluney et } \\
\text { al. (2014) }\end{array}$ & $\begin{array}{l}\text { To understand the strong } \\
\text { influences that upstream and } \\
\text { watershed processes can } \\
\text { have, including human } \\
\text { modifications, this research } \\
\text { conceptualises rivers as } \\
\text { 'macrosystems' of repeating, } \\
\text { interacting habitat patches, } \\
\text { distributed throughout } \\
\text { watersheds and along } \\
\text { hydrologic flow paths, where } \\
\text { ecological responses of } \\
\text { whole basins reflect } \\
\text { cumulative and emergent } \\
\text { properties and processes } \\
\text { operating across scales. }\end{array}$ & $\begin{array}{l}\text { REGION } \\
\text { BASIN } \\
\text { SUB-BASIN / VALLEY } \\
\text { SEGMENT } \\
\text { REACH } \\
\text { POOL-RIFFLE } \\
\text { MICROHABITAT }\end{array}$ & $\begin{array}{l}\text { No formal historical } \\
\text { analysis but human } \\
\text { interventions (land } \\
\text { cover, dams etc.) are } \\
\text { explicitly included, and } \\
\text { temporal asynchronies } \\
\text { are acknowledged. }\end{array}$ & $\begin{array}{l}\text { Macrosystem 'sensitivity', 'resistance' } \\
\text { and 'resilience' are explored through } \\
\text { an analysis of networks of reaches } \\
\text { within which changes induced, for } \\
\text { example, by human interventions can } \\
\text { be explored. }\end{array}$ & No explicit classifications. & $\begin{array}{l}\text { The conceptual framework } \\
\text { lends itself to the } \\
\text { consideration of the impact of } \\
\text { different scenarios. }\end{array}$ \\
\hline $\begin{array}{l}\text { Rinaldi et al. } \\
(2013, \\
2015 a)\end{array}$ & $\begin{array}{l}\text { A methodological framework } \\
\text { for hydromorphological } \\
\text { assessment, analysis and } \\
\text { monitoring (IDRAIM) aimed at } \\
\text { integrating objectives of } \\
\text { ecological quality and flood } \\
\text { risk mitigation. }\end{array}$ & $\begin{array}{l}\text { CATCHMENT } \\
\text { PHYSIOGRAPHIC UNIT } \\
\text { SEGMENT } \\
\text { REACH } \\
\text { GEOMORPHIC UNIT }\end{array}$ & $\begin{array}{l}\text { Historical analysis is } \\
\text { used to reconstruct the } \\
\text { trajectories of channel } \\
\text { evolution, and to } \\
\text { establish human } \\
\text { interventions (gravel } \\
\text { extraction, dam } \\
\text { construction, } \\
\text { realignment etc) and } \\
\text { human-induced changes } \\
\text { in processes (e.g. flow, } \\
\text { sediment discharge). }\end{array}$ & $\begin{array}{l}\text { The index of reach } \\
\text { hydromorphological condition (Rinaldi } \\
\text { et al., 2013) integrates scores on } 28 \\
\text { indicators of reach functionality, } \\
\text { artificiality and channel adjustments. } \\
\text { Additional indicators are used to } \\
\text { evaluate channel dynamics. }\end{array}$ & $\begin{array}{l}16 \text { RIVER REACH TYPES defined } \\
\text { according to their level of } \\
\text { confinement, planform, and bed } \\
\text { configuration. } \\
\text { Hydromorphological condition is } \\
\text { assessed by quantifying catchment to } \\
\text { reach scale indicators of functionality, } \\
\text { artificiality (and relevant historical } \\
\text { changes) and channel adjustments. }\end{array}$ & $\begin{array}{l}\text { A series of possible } \\
\text { intervention scenarios can be } \\
\text { formulated, and a general } \\
\text { decision-making framework is } \\
\text { provided on how to identify } \\
\text { the best scenario. }\end{array}$ \\
\hline
\end{tabular}

1 'classification' refers to the assignment of spatial units (e.g. reaches, segments) to distinct categories or classes based on specific attributes 
Table 2. Spatial units included within the REFORM framework: descriptions, indicative time and space scales, delineation criteria

\begin{tabular}{|c|c|c|c|}
\hline $\begin{array}{c}\text { Spatial Unit } \\
\text { (alternative equivalent terms) }\end{array}$ & $\begin{array}{l}\text { Indicative space } \\
\text { and time scales }\end{array}$ & Description & Delineation criteria \\
\hline $\begin{array}{l}\text { Region } \\
\text { (Ecoregion, Biogeographical } \\
\text { region) }\end{array}$ & $\begin{array}{l}>10^{4} \mathrm{~km}^{2} \\
>10^{4} \text { years }\end{array}$ & $\begin{array}{l}\text { Relatively large area that contains characteristic assemblages } \\
\text { of natural communities and species that are the product of the } \\
\text { broad influence of climate, relief, tectonic processes, etc. }\end{array}$ & $\begin{array}{l}\text { Differences in main climatic variables and distribution of main } \\
\text { vegetation types. }\end{array}$ \\
\hline $\begin{array}{l}\text { Catchment } \\
\text { (Drainage basin, Watershed) }\end{array}$ & $\begin{array}{l}10^{2}-10^{5} \mathrm{~km}^{2} \\
10^{3}-10^{4} \text { years }\end{array}$ & Area of land drained by a river and its tributaries. & Topographic divide (watershed). \\
\hline $\begin{array}{l}\text { Landscape Unit } \\
\text { (Physiographic Unit) }\end{array}$ & $\begin{array}{l}10^{2}-10^{3} \mathrm{~km}^{2} \\
10^{2}-10^{3} \text { years }\end{array}$ & $\begin{array}{l}\text { Portion of a catchment with similar landscape morphological } \\
\text { characteristics (topography / landform assemblage). }\end{array}$ & $\begin{array}{l}\text { Topographic form (elevation, relief - dissection, often reflecting rock } \\
\text { type(s) and showing characteristic land cover assemblages). }\end{array}$ \\
\hline $\begin{array}{l}\text { Segment } \\
\text { (Sector) }\end{array}$ & $\begin{array}{l}10^{1}-10^{2} \mathrm{~km} \\
10^{1}-10^{2} \text { years }\end{array}$ & $\begin{array}{l}\text { Section of river subject to similar valley-scale influences and } \\
\text { energy conditions. }\end{array}$ & $\begin{array}{l}\text { Major changes of valley gradient. } \\
\text { Major tributary confluences (significantly increasing upstream } \\
\text { catchment area, river discharge). } \\
\text { Valley confinement (confined, partly-confined, unconfined). } \\
\text { In mountainous areas, very large lateral sediment inputs. }\end{array}$ \\
\hline Reach & $\begin{array}{l}10^{-1}-10^{1} \mathrm{~km} \\
(20+\text { channel } \\
\text { widths }) \\
10^{1}-10^{2} \text { years }\end{array}$ & $\begin{array}{l}\text { Section of river along which boundary conditions are } \\
\text { sufficiently uniform that the river maintains a near consistent } \\
\text { internal set of process-form interactions. }\end{array}$ & $\begin{array}{l}\text { Channel morphology (particularly planform). } \\
\text { Floodplain features (minor changes in downstream slope, sediment } \\
\text { calibre, may be relevant). } \\
\text { Artificial discontinuities that affect longitudinal continuity (e.g. dams, } \\
\text { major weirs / check dams that disrupt water and sediment transfer). }\end{array}$ \\
\hline $\begin{array}{l}\text { Geomorphic unit } \\
\text { (Morphological unit, } \\
\text { Mesohabitat, Sub-reach) }\end{array}$ & $\begin{array}{l}10^{0}-10^{2} \mathrm{~m} \\
(0.1-20 \text { channel } \\
\text { widths }) \\
10^{0}-10^{1} \text { years }\end{array}$ & $\begin{array}{l}\text { Area containing a landform created by erosion or deposition of } \\
\text { sediment, sometimes in association with vegetation. } \\
\text { Geomorphic units can be located within the channel (bed and } \\
\text { mid-channel features), along the channel edges (marginal and } \\
\text { bank features) or on the floodplain. }\end{array}$ & $\begin{array}{l}\text { Major morphological units of the channel or floodplain distinguished } \\
\text { by distinct form, sediment structure / calibre, water depth / velocity } \\
\text { structure and sometimes large wood or plant stands (e.g. aquatic / } \\
\text { riparian, age class). }\end{array}$ \\
\hline Hydraulic unit & $\begin{array}{l}10^{-1}-10^{1} \mathrm{~m} \\
\left(5-20 \mathrm{D}_{50}\right) \\
10^{-1}-10^{1} \text { years }\end{array}$ & $\begin{array}{l}\text { Spatially distinct patch of relatively homogeneous surface flow } \\
\text { and substrate character. A single geomorphic unit can include } \\
\text { from one to several hydraulic units. }\end{array}$ & $\begin{array}{l}\text { Patches with a consistent flow depth / velocity / bed shear stress for } \\
\text { any given flow stage and characterized by a narrow range in } \\
\text { sediment particle size. }\end{array}$ \\
\hline River element & $\begin{array}{l}10^{-2}-10^{1} \mathrm{~m} \\
\left(10^{0}-10^{1} \mathrm{D}_{50}\right) \\
10^{-2}-10^{0} \text { years }\end{array}$ & $\begin{array}{l}\text { Element of river environments including an individual and } \\
\text { patches of sediment particles, plants, wood. }\end{array}$ & Significant isolated elements creating specific habitat types. \\
\hline
\end{tabular}

$D_{50}$ - median particle size of the river bed material 
Table 3. Examples of indicators and the processes they indicate at catchment to reach scales of the REFORM framework (for further details see González del Tánago et al. (2015a))

\begin{tabular}{|c|c|c|}
\hline SCALE & KEY PROCESSES & EXAMPLE INDICATORS \\
\hline Catchment & Water production & Average annual precipitation, Average annual water yield \\
\hline \multirow[t]{2}{*}{$\begin{array}{l}\text { Landscape } \\
\text { Unit }\end{array}$} & $\begin{array}{l}\text { Runoff production / } \\
\text { retention }\end{array}$ & $\%$ Exposed aquifers, \% Soil permeability class, \% land cover classes \\
\hline & $\begin{array}{l}\text { Fine and coarse sediment } \\
\text { production }\end{array}$ & Annual soil erosion, Coarse sediment source areas \\
\hline \multirow{5}{*}{$\begin{array}{l}\text { River } \\
\text { Segment }\end{array}$} & Valley features & Valley confinement and gradient, River confinement \\
\hline & Flow regime and extremes & $\begin{array}{l}\text { Flow regime type, Average annual flow, Base flow index, Median, } 2 \\
\text { year and } 10 \text { year floods }\end{array}$ \\
\hline & $\begin{array}{l}\text { Sediment delivery and } \\
\text { transport regime }\end{array}$ & Eroded soil delivery, Segment sediment budget \\
\hline & $\begin{array}{l}\text { Disruption of longitudinal } \\
\text { continuity }\end{array}$ & $\begin{array}{l}\text { Number of major blocking and spanning structures (e.g. dams, drop } \\
\text { structures, weirs, bridges) }\end{array}$ \\
\hline & $\begin{array}{l}\text { Riparian corridor size, } \\
\text { functions, succession, } \\
\text { wood delivery }\end{array}$ & $\begin{array}{l}\text { Average riparian corridor width, Continuity of riparian vegetation } \\
\text { along river edge, Age structure of riparian vegetation }\end{array}$ \\
\hline \multirow[t]{7}{*}{ Reach } & Stream power & Specific stream power at contemporary bankfull width \\
\hline & Flooding extent & \% Floodplain accessible by flood water \\
\hline & $\begin{array}{l}\text { Channel type and } \\
\text { dimensions }\end{array}$ & $\begin{array}{l}\text { Channel type, Floodplain type, Average bankfull channel width, } \\
\text { depth and slope, Bed and bank sediment size, Presence of } \\
\text { geomorphic units typical of channel and floodplain type }\end{array}$ \\
\hline & $\begin{array}{l}\text { Contemporary evidence of } \\
\text { channel adjustments }\end{array}$ & $\begin{array}{l}\text { Eroding, laterally aggrading banks, Channel widening, narrowing, } \\
\text { bed incision, bed aggradation, Vegetation encroachment }\end{array}$ \\
\hline & $\begin{array}{l}\text { Historical evidence of } \\
\text { channel adjustments. }\end{array}$ & $\begin{array}{l}\text { Changes in channel width, Sinuosity, braiding, anabranching indices, } \\
\text { Rate of lateral channel movement }\end{array}$ \\
\hline & $\begin{array}{l}\text { Constraints on channel } \\
\text { adjustments, water, } \\
\text { sediment, wood continuity }\end{array}$ & $\begin{array}{l}\text { Average width of erodible corridor, Longitudinal continuity, Lateral } \\
\text { continuity }\end{array}$ \\
\hline & $\begin{array}{l}\text { Vegetation dynamics } \\
\text { (riparian, aquatic } \\
\text { vegetation and wood) }\end{array}$ & $\begin{array}{l}\text { \% Riparian corridor under riparian vegetation, Riparian vegetation } \\
\text { age structure, Large wood and fallen trees in channel and riparian } \\
\text { corridor, Abundance of riparian tree and large wood associated } \\
\text { geomorphic units, Aquatic plant extent, Abundance of aquatic plant } \\
\text { associated geomorphic }\end{array}$ \\
\hline
\end{tabular}


Table 4. Pan European data sources that are mainly freely available and can support delineation and characterisation of spatial units

\begin{tabular}{|c|c|c|c|}
\hline Data set / source & Description & Web link & Information Type \\
\hline $\begin{array}{l}\text { Synthesis of several } \\
\text { primary data sources }\end{array}$ & $\begin{array}{l}\text { Biogeographic Regions and } \\
\text { Subregions }\end{array}$ & $\begin{array}{l}\text { www.globalbioclimatics.org } \\
\text { http://www.eea.europa.eu/data-and- } \\
\text { maps/figures/biogeographical-regions-europe-2001 }\end{array}$ & Maps of Regions \\
\hline ASTER GDEM & $\begin{array}{l}30 \mathrm{~m} \text { resolution, } 7-14 \mathrm{~m} \text { vertical } \\
\text { accuracy }\end{array}$ & http://asterweb.jpl.nasa.gov/gdem.asp & Topographic \\
\hline EU-DEM & $\begin{array}{l}\text { Pan-EU DEM at } 25 \mathrm{~m} \text { based on } \\
\text { ASTER GDEM m (higher quality than } \\
\text { any other publicly available DEM at EU } \\
\text { scale) }\end{array}$ & $\begin{array}{l}\text { http://epp.eurostat.ec.europa.eu/portal/page/portal/gisco_G } \\
\text { eographical_information_maps/geodata/digital_elevation_ } \\
\text { model }\end{array}$ & Topographic \\
\hline NASA SRTM3 DEM & $90 \mathrm{~m}$ resolution, $10 \mathrm{~m}$ vertical accuracy & $\begin{array}{l}\text { http://www2.jpl.nasa.gov/srtm/ } \\
\text { http://glovis.usgs.gov/ }\end{array}$ & Topographic \\
\hline JRC CID Portal & $\begin{array}{l}\text { High resolution }(1,2,5,10 \mathrm{~m}) \text { satellite } \\
\text { imagery, spatial coverage and dates } \\
\text { vary }\end{array}$ & http://cidportal.jrc.ec.europa.eu/imagearchive/main/ & Channel planform, vegetation/land use \\
\hline \begin{tabular}{|l} 
Image 2000 Satellite \\
Imagery
\end{tabular} & $\begin{array}{l}12.5 \mathrm{~m} \text { resolution (panchromatic), } 25 \mathrm{~m} \\
\text { (multispectral) }\end{array}$ & $\begin{array}{l}\text { http://image2000.jrc.ec.europa.eu/index.cfm/page/image20 } \\
\text { 00_overview }\end{array}$ & Channel planform, vegetation/land use \\
\hline \begin{tabular}{|l} 
LandSat $(4,5,7,8)$ \\
Satellite Imagery
\end{tabular} & $\begin{array}{l}30 \mathrm{~m} \text { resolution (15m from } 1999), \\
1982 \text {-present }\end{array}$ & $\begin{array}{l}\text { http://earthexplorer.usgs.gov/ } \\
\text { http://glovis.usgs.gov/ }\end{array}$ & Channel planform, vegetation/land use \\
\hline \begin{tabular}{|l|} 
Declassified Satellite \\
Imagery (Corona, KH-7, \\
KH-9)
\end{tabular} & $\begin{array}{l}\text { 1'-50' resolution, } 1960-1980, \text { spatial } \\
\text { coverage varies }\end{array}$ & |http://earthexplorer.usgs.gov/ & Channel planform, vegetation/land use \\
\hline European Water Archive & $\begin{array}{l}\text { Flow data (daily/monthly) from } 3800 \\
\text { gauging stations, } 441 \text { are near-natural } \\
\text { catchments }\end{array}$ & $\begin{array}{l}\text { http://www.bafg.de/GRDC/EN/04_spcldtbss/42_EWA/ewa. } \\
\text { html }\end{array}$ & Hydrology \\
\hline CCM2 Database & $\begin{array}{l}\text { Pan-European database of river } \\
\text { networks and catchments }\end{array}$ & $\begin{array}{l}\text { http://ccm.jrc.ec.europa.eu/php/index.php?action=view\&id= } \\
23\end{array}$ & $\begin{array}{l}\text { Inferred channel network from DEM, } \\
\text { catchment boundaries and } \\
\text { characteristics }\end{array}$ \\
\hline $\begin{array}{l}\text { Ecrins - European } \\
\text { catchments and rivers } \\
\text { network system }\end{array}$ & $\begin{array}{l}\text { Improved river network based on } \\
\text { CCM2, FEC - functional elemental } \\
\text { catchments based on Strahler number }\end{array}$ & $\begin{array}{l}\text { http://www.eea.europa.eu/data-and-maps/data/european- } \\
\text { catchments-and-rivers-network }\end{array}$ & $\begin{array}{l}\text { Inferred channel network from DEM, } \\
\text { catchment boundaries, lakes }\end{array}$ \\
\hline Corine Land Cover & $\begin{array}{l}\text { Land cover data }(1990,2000,2006) \\
\text { resolution }=100 \mathrm{~m}\end{array}$ & http://www.eea.europa.eu/data-and-maps & Land use / cover \\
\hline One Geology Europe & $\begin{array}{l}\text { Surficial geology coverage for Europe, } \\
\text { resolution varies }\end{array}$ & http://www.onegeology.org/ & Geology \\
\hline
\end{tabular}

